(C) Гімаєва Ю. А., Васіна М. О., 2017

\author{
Гімасва Юлія Азгатіна, \\ Васіна Маргарита Олександрівна
}

Харківський національний університет імені В. Н. Каразіна

\title{
ЗВ'ЯЗОК ЕМОЦЙНИХ ОСОБЛИВОСТЕЙ ЗІ ЗДАТНІСТЮ ДО НАВЧАННЯ ТА ГОТОВНІСТЮ ДО ШКОЛИ У ПЕРШОКЛАСНИКІВ
}

Статтю присвячено проблемі зв'язку емоційних особливостей зі здатністю до навчання $i$ готовністю до школи та обумовлення здатності до навчання в учнів першого класу. Традииійно здатність до навчання як сприйнятливість дитини до навчальної діяльності пов'язують з інтелектуальним розвитком. Проте є підстави думати про ії зв'язок також з емоційними властивостями та станами дитини. У даному дослідженні порівнювались учні перших класів лічею та загальноосвітньої школи за рівнем здатності до навчання, типами готовності до школи (учбовий, передучбовий, псевдоучбовий, дошкільний), емочійними особливостями (тривожність, ворожість, депресивність, незахищеність, недовіра до себе, почуття неповноиінності та ін.). Було застосовано кореляційний і регресійний аналіз та виявлено, що здатність до навчання значною мірою залежить від емоційних особливостей учнів, а саме - від тривожності, депресивності, незахищеності і фрустрованості.

Ключові слова: емочійні особливості, здатність до навчання, готовність до школи, першокласник, регресійний аналіз.

Проблема, її зв'язок з важливими практичними завданнями. Проблема готовності дітей до навчання у школі не перестає бути актуальною, тим більш сьогодні, коли до першого класу приходять діти шести років і навіть молодше. Психологічна готовність до школи $\epsilon$ передумовою для успішної адаптації учня до школи та засвоєння навчальної програми, що дає змогу прогнозувати навіть академічну успішність учня. Натомість сам процес навчання може бути досить стресовим для молодших школярів, тому треба ураховувати різні фактори, що впливають на прояв здатності оволодівати знаннями й навичками у молодших школярів.

Аналіз стану розробки проблеми. За своїм складом психологічна готовність до школи - це комплексне утворення, що включає в себе наявність певного рівня розвитку пізнавальних 
процесів, довільності, мотивації до навчання, засвоєння комунікативних навичок, орієнтації у відносинах 3 дорослими i однолітками (Л. І. Божович, Д. Б. Ельконін, Й. Шванцара, О. В. Запорожець, В. С. Мухіна, О. С. Кравцова). Значну роль у цьому комплексі відіграє й здатність до навчання, яку розуміють як сприйнятливість дитини до навчальної діяльності, здатність оволодіти новими вміннями, способами дій і взагалі відкривати нові знання (Л. С. Виготський, Б. В. Зейгарнік, Н. О. Менчинська, 3. І. Калмикова, Б. Г. Анан'єв, В. М. Дружинін, А. Я. Іванова).

Зазвичай здатність до навчання напряму поєднують 3 інтелектуальними здібностями дитини. При цьому поза увагою дослідників залишаються емоційні особливості дітей, хоча кожному практику відомо, що певні емоційні стани можуть суттєво обмежувати прояв здібностей. Це з власного досвіду знає й кожний дорослий, і тим більш це стосується дітей, які ще не володіють необхідними механізмами саморегуляції. Тож логічним було б врахувати особливості емоційної сфери як фактору впливу на здатність до навчання та готовність до школи.

Метою дослідження було виявити зв'язок емоційних особливостей першокласників 3 їх здатністю до навчання та типом готовності до школи.

Для збору емпіричних даних були використані наступні методики: навчальний експеримент А. Я. Іванової «Класифікація геометричних фігур» для дослідження здатності до навчання [4], методика «Розмальовка» А. Л. Венгера і К. М. Поліванової для виявлення типу готовності до школи [2, 37-39], методика «Будинок, дерево, людина» у модифікації Р. Ф. Беляускайте [1]. Для статистичної обробки даних були використані t-критерій Стьюдента, U-критерій Вілкоксона, Манна-Уітні, кореляційний та регресійний аналіз.

У дослідженні брали участь 50 першокласників віком 6-7 років: 25 учнів ліцею № 89 та 25 учнів загальноосвітньої школи № 52 м. Харкова. Всього 22 хлопчика і 28 дівчаток.

Виклад та обговорення результатів емпіричного дослідження.

За отриманими даними у переважної кількості першокласників (92\%) здатність до навчання відповідає нормі. У ліцеїстів цей показник все ж значущо кращий, ніж в учнів загальноосвітньої школи. Проте ці розбіжності пояснюються, скоріше, системою відбору учнів до ліцею, ніж власне особливостями групи. Натомість показово, що сучасним дітям знадобилась менша кількість «підказок» порівняно з класичними даними А.Я. Іванової, що вказує на зміни ситуації розвитку (поява розвивальних іграшок, студій раннього розвитку та ін.), що надають нових можливостей для прогресивного розвитку. 


\section{Збірник наукових статей}

Дані розподілу типів готовності дітей до школи наведені в табл. 1. Таблиия 1 Кількість учнів з різними типами готовності до школи (у \%)

\begin{tabular}{|l|c|c|}
\hline \multicolumn{1}{|c|}{ Тип готовності } & Ліцей & 3ОШ \\
\hline Дошкільний тип & $4 \%$ & $16 \%$ \\
\hline Псевдоучбовий тип & $36 \%$ & $44 \%$ \\
\hline Передучбовий тип & $20 \%$ & $28 \%$ \\
\hline Учбовий тип & $40 \%$ & $12 \%$ \\
\hline
\end{tabular}

Серед першокласників ліцею найчастіше зустрічається учбовий тип готовності до школи (40\%), що у три з половиною рази частіше, ніж серед учнів перших класів у ЗОШ (12\%). Псевдоучбовий тип, навпаки, більш розповсюджений серед першокласників загальноосвітньої школи (44\%). У ліцеїстів цей тип менш виражений, але також притаманний значній частині учнів (36\%). Приблизно однакова кількість учнів, і в ЗОШ (28\%), і в ліцеї (20\%), має передучбовий тип готовності до школи, але у загальноосвітній школі, все ж таки, він зустрічається частіше. Найрідше серед першокласників ліцею зустрічається дошкільний тип готовності до школи (4\%), що у чотири рази менше, ніж серед першокласників ЗОШ (16\%), де учнів дошкільного типу навіть більше, ніж учбового.

Дані 3 вираженості симптомокомплексів за методикою «Будинок, дерево, людина» наведені у табл. 2.

Таблиия 2

Вираженість симптомокомплексів за методикою «Будинок, дерево, людина» (у \%)

\begin{tabular}{|l|c|c|c|}
\hline \multicolumn{1}{|c|}{ Симптомокомплекси } & Ліцей & $30 Ш$ & $\mathrm{p}$ \\
\hline Незахищеність & $33 \%$ & $26 \%$ & 0,041 \\
\hline Тривожність & $26 \%$ & $33 \%$ & $\begin{array}{c}0,052 \\
\text { (тенденція) }\end{array}$ \\
\hline Недовіра до себе & $15 \%$ & $16 \%$ & \\
\hline Почуття неповноцінності & $15 \%$ & $15 \%$ & \\
\hline Ворожість & $19 \%$ & $21 \%$ & \\
\hline Конфліктність (фрустрація) & $15 \%$ & $16 \%$ & \\
\hline Труднощі спілкування & $22 \%$ & $25 \%$ & \\
\hline Депресивність & $11 \%$ & $12 \%$ & \\
\hline
\end{tabular}

У всіх першокласників відносно сильно виражені незахищеність, тривожність, труднощі спілкування і ворожість. У ліцеїстів найбільш вираженою (33\%) є незахищеність, яка також 
виражена значущо більш, ніж в учнів загальноосвітньої школи (26\%). Це можна пояснити тим, що до дітей в ліцеї ставляться більш вибагливі вимоги, ніж до дітей 3 загальноосвітньої школи. Тривожність, ворожість і труднощі спілкування дещо більше притаманні учням ЗОШ. Найбільш сильно вираженою 3 них $\epsilon$ тривожність (33\% проти $26 \%$ в ліцеїстів), причиною чого між іншим може бути сама побудова навчального процесу, внаслідок чого учбова тривожність може заміняти пізнавальний інтерес дитини [3]. Труднощі спілкування виражені на 25\% (в ліцеїстів - на 22\%), ворожість - на $21 \%$ i 19\% відповідно. Ці симптомокомплекси можуть мати як соціально-психологічне походження, так і співзалежати як один від одного, так і від тривожності.

Недовіра до себе, почуття неповноцінності та конфліктність (фрустрація) виражені у першокласників помірно і майже однаково. Найслабшим емоційним симптомокомплексом $є$ депресивність.

Кореляційний аналіз виявив загалом у першокласників зворотні зв'язки здатності до навчання 3 тривожністю $(\mathrm{p}<0,05)$ й депресивністю $(\mathrm{p}<0,05)$, а також прямий зв'язок $(\mathrm{p}<0,01) 3$ типом готовності до школи (чим краща в дитини здатність до навчання, тим більше показник типу навчання наближається до продуктивного ). У ліцеїстів крім того здатність до навчання зворотно пов'язана 3 недовірою до себе $(\mathrm{p}<0,05)$. В учнів загальноосвітньої школи здатність до навчання зворотно пов'язана з труднощами спілкування $(\mathrm{p}<0,05)$, а тип готовності до школи -3 депресивністю $(\mathrm{p}<0,05)$. Тобто чим гірша в учня здатність до навчання, тим більше в ного комунікативних утруднень, чим менш сприятливий тип готовності до школи (менш відповідний до навчальної діяльності) має учень, тим у нього більший рівень депресивності.

Та найцікавіші дані були отримані за допомогою регресійного статистичного аналізу щодо зв'язку здатності до навчання першокласників та їх емоційних особливостей (див. табл. 3). Було 3'ясовано, що рівень здатності до навчання дійсно на 46\% залежить від емоційних особливостей першокласників. Найбільший влив мають такі особливості як: тривожність $(-0,0005)$, депресивність $(-0,0081)$, фрустрація $(-0,0304)$ та незахищеність $(-0,0579)$. Усі вони вливають на здатність до навчання у одному напрямку: чим вищі їх прояви, тим нижчий рівень здатності навчання.

За допомогою регресійного аналізу було також виявлено, що тип готовності до школи залежить від емоційних особливостей першокласників в значно меншій мірі (13\%), ніж здатність до навчання. 
Обумовлення здатності до навчання особливостями емоційної сфери

\begin{tabular}{|c|c|c|c|}
\hline $\begin{array}{c}\text { Впливовий фактор } \\
\text { (предиктор) }\end{array}$ & $\begin{array}{c}\text { Р- } \\
\text { значення }\end{array}$ & $\begin{array}{c}\text { Залежність } \\
(\%)\end{array}$ & $\begin{array}{l}\text { Залежний } \\
\text { фактор }\end{array}$ \\
\hline Незахищеність & $-0,0579$ & \multirow{8}{*}{$46 \%$} & \multirow{8}{*}{$\begin{array}{c}\text { Здатність до } \\
\text { навчання }\end{array}$} \\
\hline Тривожність & $-0,0005$ & & \\
\hline Недовіра до себе & $-0,9747$ & & \\
\hline Почуття неповноцінності & $-0,3063$ & & \\
\hline Ворожість & $-0,7596$ & & \\
\hline $\begin{array}{l}\text { Конфліктність } \\
\text { (фрустрація) }\end{array}$ & $-0,0304$ & & \\
\hline Труднощі спілкування & $-0,1642$ & & \\
\hline Депресивність & $-0,0081$ & & \\
\hline
\end{tabular}

\section{Висновки.}

1. Здатність до навчання перебуває в межах норми у переважної більшості першокласників, тільки незначна кількість учнів мають розумове відхилення чи пограничний стан. Здатність до навчання залежить від навчального закладу: у першокласників ліцею вона значуще вища, ніж у першокласників загальноосвітньої школи. Також ліцеїстам знадобилася значуще менша кількість підказок, ніж учням ЗОШ. Порівняно з класичними даними середня кількість «уроківпідказок» виявилась меншою майже в два рази, що вказує на суттєве зростання у дітей здатності до навчання.

2. Першокласникам-ліцеїстам найбільш притаманні учбовий i псевдоучбовий типи готовності до школи. Вони розподіляються практично однаковою мірою та разом характеризують майже три чверті учнів. У п'ятої частини ліцеїстів виявлено передучбовий тип, дошкільний тип зустрічається досить рідко. Першокласникам ЗОШ найбільш притаманний (майже половині) псевдоучбовий тип готовності до школи. Біля третини учнів мають передучбовий тип, помітно часто зустрічається дошкільний тип готовності (в чотири рази частіше, ніж в ліцеї), і тільки в кожної восьмої дитини - учбовий тип (втричі рідше, ніж в ліцеї).

3. Значною мірою у першокласників як ліцею, так $\mathrm{i}$ загальноосвітньої школи виражені почуття незахищеності, тривожність, труднощі спілкування та ворожість. Почуття незахищеності на статистично значущому рівні більш притаманне ліцеїстам, а тривожність - помітно більше учням ЗОШ, труднощі спілкування і ворожість також дещо більші у першокласників із ЗОШ. У всіх дітей недовіра до себе, почуття неповноцінності та фрустрація виражені помірно, а депресивність - найслабіше. 
4. У всіх першокласників здатність до навчання прямо пов'язана 3 типом готовності до школи та зворотно 3 тривожністю й депресивністю. У ліцеїстів здатність до навчання додатково зворотно пов'язана $з$ недовірою до себе, а в першокласників загальноосвітньої школи - 3 труднощами спілкування. Депресивність в учнів ЗОШ зворотно пов'язана з типом готовності до школи.

5. Емоційні особливості першокласників на значущому рівні визначають здатність до навчання. Такими предикторами $\epsilon$ тривожність, депресивність фрустрація й почуття незахищеності. Тип готовності до школи визначається особливостями емоційної сфери суттєво менше.

Перспективи. У подальшому цікаво було б розширити перелік емоційних особливостей, включаючи емоційні властивості і риси особистості, та дослідити їх вплив на здатність до навчання.

1. Беляускайте Р. Ф. $\quad \begin{array}{ll}\text { Література } \\ \text { Рисуночные пробы как средство }\end{array}$ диагностики развития ребёнка / Р. Ф. Беляускайте // Диагностическая и коррекционная работа школьного психолога / Отв. Ред. И. В. Дубровина. - М. : Изд-во АПН СССР, 1987. - С. 67-80.

2. Бугрименко Е. А. Готовность детей к школе. Диагностика психического развития и коррекция его неблагоприятных вариантов. Методические разработки для школьного психолога / Е. А. Бугрименко, А. Л. Венгер, К. Н. Поливанова, Е.Ю. Сушкова. М. : ВНИК «Школа», 1989. - 88 с.

3. Дусавицкий А. К. Зависимость между интересом и тревожностью в учебной деятельности младших школьников / А. К. Дусавицкий. // Вопросы психологии. - 1982. -№ 3 - С. 56-61.

4. Иванова А. Я. Обучаемость как принцип оценки умственного развития детей / А. Я. Иванова. - М. : МГУ, 1976. - 97 с.

\section{Юлия Гимаева, Маргарита Васина. Связь эмоциональных особенностей с обучаемостью и готовностью к школе у первоклассников.}

В статье рассматривается вопрос связи эмочиональных особенностей с обучаемостью и готовностью к обучению в школе $и$ проблема факторов, которые обусловливают обучаемость, у учеников первого класса. Стандартно обучаемость у детей, как восприимчивость $\kappa$ учебной деятельности, связывают $c$ интеллектуальным развитием. Но есть основания предполагать, что она также связана и с эмоциональными особенностями $u$ состояниями детей. В данном исследовании сравнивались ученики первых классов лищея и общеобразовательной школь по уровню 
обучаемости, распределению типов готовности к иколе (учебного, предучебного, псевдоучебного, дошкольного), выраженности эмоциональных особенностей (тревожности, враждебности, депрессивности, незащищённости, недоверия $\kappa$ себе, чувства неполноченности и др.). Был использован корреляционный $u$ регрессионный анализ и выявлено, что обучаемость в значительной мере зависит от эмочиональных особенностей учеников, таких как тревожность, депрессивность, фрустрированность $u$ незашищеённость.

Ключевые слова: эмоциональные особенности, обучаемость, готовность к школе, первоклассник, регрессионный анализ.

\begin{abstract}
Yuliya Gimayeva, Marharyta Vasina. Connection of emotional properties with ability to study and willingness to study in the first-year pupils.

The article is devoted to the problem of connection of emotional properties with ability to study and willingness to study and determining the ability to study in the first-year pupils. Traditionally, the ability to study is associated with intellectual development. However, there are some reasons to think about its connection with the emotional properties and the child's states. In this study, the first-year pupils of the lyceum and comprehensive school were compared with their level of ability to study, types of willingness to study and some emotional features. The correlation and regression analyzes were applied and it was found that ability to study mostly depends on emotional features of the pupils such as anxiety, depression, frustration and insecurity.
\end{abstract}

Keywords emotional properties, ability to study, willingness to study, firstyear pupil, regression analyzes.

Стаття надійшла до редакційної колегії 31.10.2017

\title{
Інформація про авторів:
}

Гімаєва Юлія Азгатівна - кандидат психологічних наук, доцент, Харківський національний університет імені В. Н. Каразіна.

Васіна Маргарита Олександрівна - магістр, Харківський національний університет імені В. Н. Каразіна. 